\title{
Characterization of the novel duplicated PRLR gene at the late-feathering $K$ locus in Lohmann chickens
}

\section{Guixian Bu*, Guian Huang*, Hao Fu, Juan Li, Simiao Huang and Yajun Wang}

Key Laboratory of Bio-resources and Eco-environment of Ministry of Education, College of Life Sciences, Sichuan University, Chengdu 610065, People's Republic of China

*(G Bu and G Huang contributed equally to this work)
Correspondence should be addressed to $Y$ Wang

Email

cdwyjhk@gmail.com

\begin{abstract}
A partial duplication of the prolactin (PRL) receptor gene (designated as $d P R L R$ ) has been identified at the late-feathering (LF) $K$ locus on chromosome $Z$ of some chicken strains recently, implying that $d P R L R$ is probably a candidate gene associated with LF development in chickens. However, little is known about the structure, functionality, and spatiotemporal expression of the $d P R L R$ gene in chickens. In this study, using $3^{\prime}-R A C E$ and RT-PCR, the full-length cDNA of the $d P R L R$ obtained from the kidneys of male Lohmann layer chickens carrying a $K$ allele was cloned. The cloned $d P R L R$ is predicted to encode a membranespanning receptor of 683 amino acids, which is nearly identical to the original PRLR, except for its lack of a 149-amino acid C-terminal tail. Using a $5 \times$ STAT5-Luciferase reporter system and western blot analysis, we demonstrated that dPRLR expressed in HepG2 cells could be potently activated by chicken PRL and functionally coupled to the intracellular STAT5 signaling pathway, suggesting that dPRLR may function as a novel receptor for PRL. RT-PCR assays revealed that similar to the original PRLR gene, $d P R L R$ mRNA is widely expressed in all embryonic and adult tissues examined including the skin of male Lohmann chickens with a $K$ allele. These findings, together with the expression of PRL mRNA detected in the skin of embryos at embryonic day 20 and 1-week-old chicks, suggest that skin-expressed dPRLR and PRLR, together with plasma and skin-derived PRL, may be involved in the control of the LF development of chicks at hatching. Moreover, the wide tissue expression of $d P R L R$ implies that dPRLR may regulate other physiological processes of chickens carrying the $K$ allele.
\end{abstract}
Key Words
- chickens
- duplicated prolactin receptor
- skin
- feather development

Journal of Molecular

Endocrinology

(2013) 51, 261-276

\section{Introduction}

Prolactin (PRL) is a polypeptide hormone and belongs to the growth hormone $(\mathrm{GH}) / \mathrm{PRL}$ family, which also includes somatolactin, placental lactogens, and the newly identified PRL-like (PRL-L) protein (Goffin et al. 1996, Bole-Feysot et al. 1998, Zhu et al. 2004,
Ben-Jonathan et al. 2008, Wang et al. 2010b). PRL is primarily synthesized in and released from the anterior pituitary and participates in many physiological processes including reproduction, osmoregulation, immunomodulation, behavior, and growth and development in

Published by Bioscientifica Ltd 
vertebrates (Freeman et al. 2000, Ben-Jonathan et al. 2008, Nguyen et al. 2008). It is clear that the diverse actions of PRL are mediated by the PRL receptor (PRLR), which contains a large extracellular domain, a transmembrane domain (TMD), and an intracellular domain (Bole-Feysot et al. 1998). Upon the binding of PRL, the PRLR can initiate multiple intracellular signaling cascades, including the activation of the JAK2-STAT5 signaling pathway, and thus control the subsequent expression of target genes (Bole-Feysot et al. 1998, Brooks 2012).

Specifically, in chickens, PRL has been reported to regulate a number of physiological processes, such as the initiation and maintenance of incubation behavior, immunomodulation, and regulation of gonadal development and functions (Sharp et al. 1979, 1988, Lea et al. 1981, Doneen \& Smith 1982, Talbot et al. 1991). As in mammals, the broad spectrum of PRL actions in chickens has also been reported to be mediated by a PRLR, which is encoded by a PRLR gene on chromosome $\mathrm{Z}$ and widely expressed in a variety of tissues (Tanaka et al. 1992, Ohkubo et al. 1998b, Bu et al. 2013).

Strikingly, in addition to a PRLR gene localized on chromosome $\mathrm{Z}$, a partially duplicated PRLR gene (designated as $A P R L R$ gene herein) has also been identified recently (Elferink et al. 2008). The $d P R L R$ gene was found within the sex-linked late-feathering (LF) $K$ locus on chromosome $\mathrm{Z}$, within which a partial duplication of sperm flagellar 2 gene (named dSPEF2) was identified simultaneously (Elferink et al. 2008). It has been reported that this dominant sex-linked $K$ allele is associated with the LF phenotype of newly hatched chicks with the retarded emergence of flight feathers, while the recessive $k+$ allele determines the early-feathering (EF) phenotype of chicks (Serebrovsky 1922, Elferink et al. 2008). The identification of the $d P R L R$ gene within the $K$ locus (but not within the $k+$ locus) suggests that $d P R L R$ is probably a candidate gene associated with LF development in chicks (Elferink et al. 2008, Wang et al. 2010a, Luo et al. 2012). However, some fundamental issues regarding $d P R L R$ gene remain to be addressed: i) whether the $d P R L R$ gene is expressed in various tissues of chickens carrying the $K$ allele; ii) whether the $d P R L R$ gene can encode a functional receptor for PRL; and iii) how the $d P R L R$ gene is involved in the control of the phenotypic traits of chickens, such as the LF development of chicks.

Pursuing our recent studies and focusing on the molecular characterization of chicken $P R L R$ gene (designated as the original PRLR gene herein) including its intricate gene structure, tissue expression, promoter usage, and interaction with its two ligands (PRL and PRL-L;
Wang et al. 2010b, Bu et al. 2013), the present study aims to further characterize this duplicated PRLR gene ( $d P R L R)$ within the $K$ locus in a commercial chicken strain Lohmann layer. Our results showed that $d P R L R$ is likely to encode a novel functional receptor for PRL and is widely expressed in all chicken tissues examined including the skin with a spatiotemporal expression pattern similar to that of the original PRLR gene. The results of the present study establish an important molecular basis for the elucidation of the roles of the $d P R L R$ gene in chickens further, including its potential action on feather development. Moreover, an extra copy of the PRLR gene ( $d P R L R)$, found to be ubiquitously expressed in all the tissues of chickens carrying the $K$ allele examined in this study, also suggests that chickens with different genotypes (with or without the $d P R L R$ gene) might be an ideal and unique model to decipher the diverse roles of PRLR and its ligand(s) in vertebrates, such as its roles in skin biology (Elferink et al. 2008, Foitzik et al. 2009).

\section{Materials and methods}

\section{Chemicals and hormones}

All the chemicals were obtained from Sigma-Aldrich, and restriction enzymes were obtained from Takara (Dalian, China), unless stated otherwise. Antibodies against $\beta$-actin (catalog no. 4967), STAT5 (catalog no. 9358), and phosphorylated STAT5 $\left(\mathrm{Tyr}^{694}\right.$ ) (catalog no. 4322) were purchased from Cell Signaling Technology, Inc. (Beverly, MA, USA).

\section{Total RNA extraction}

Chickens (or embryos) (Lohmann Sandy strain) were purchased from a local commercial company and killed. As an initial step toward uncovering the roles of the $d P R L R$ gene within the $K$ locus in chicken strains, only male chickens with the genotype $K / k+$ (LF phenotype) and female chickens with the genotype $k+/ w$ (EF phenotype) were used in this study (Fig. 1). The genotype of male chickens or embryos $(K / k+)$ was first examined by PCR amplification of the $78 \mathrm{bp}$ breakpoint junction fragment from genomic DNA extracted from the liver or blood as reported previously (Elferink et al. 2008, Wang et al. 2010a). Then, it was further confirmed by evaluating the copy number of the PRLR gene in chickens using quantitative real-time PCR assays (GH receptor (GHR) gene close to PRLR gene (Fig. 1) was used as an internal control to evaluate the copy number of $P R L R$ gene in each

Published by Bioscientifica Ltd. 

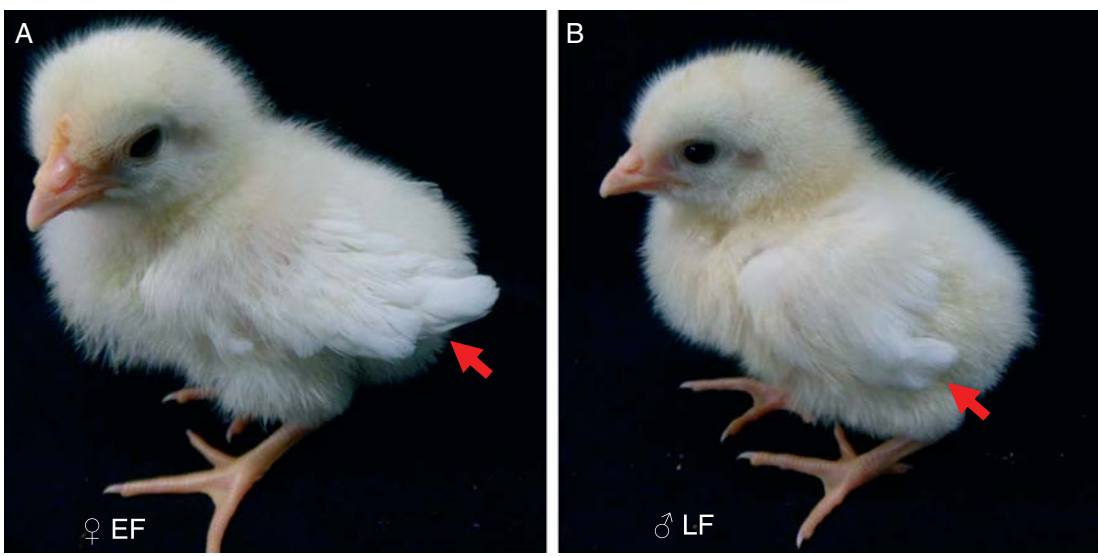

C
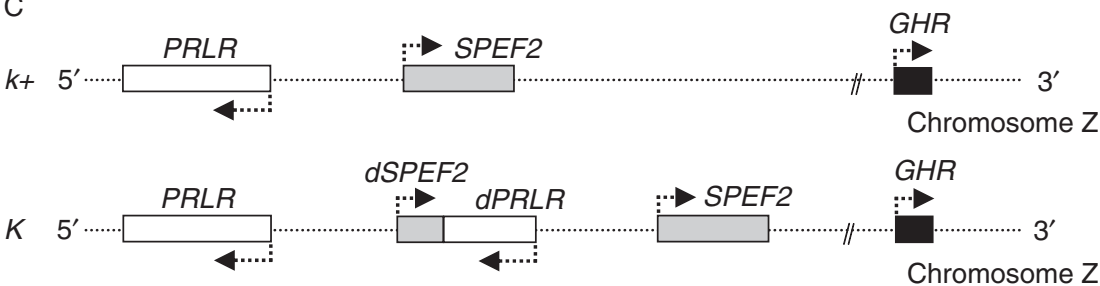

\section{Figure 1}

(A) A 6-day-old female chick with the EF phenotype (genotype $k+/ w$ ); (B) a 6-day-old male chick with the LF phenotype (genotype $K / k+$ ). Arrows in (A) and (B) indicate the different developmental status of flight feathers in the female $(E F, ~ \%)$ and male (LF, $\left.\delta^{\prime}\right)$ chicks. (C) Organization of the $k+$ allele and $K$ allele in chicken sex chromosome $Z$. The $k+$ allele contains $P R L R$ and SPEF2 genes only, while the $K$ allele contains the original PRLR and SPEF2 genes and the partially duplicated PRLR (dPRLR) and SPEF2

chicken) (Fig. 1; Supplementary Figure 1, see section on supplementary data given at the end of this article). Tissues from embryos (at embryonic day 12 (E12), E16, and E20), 1-week-old chicks, and 2-month-old and adult chickens, including the whole brain, heart, small intestine, kidneys, liver, lungs, muscle, ovaries, testis, pituitary, spleen, pancreas, and skin (around the feathers), were collected, frozen in liquid nitrogen, and stored at $-80^{\circ} \mathrm{C}$ prior to use. Total RNA was extracted from the tissues using RNAzol (Molecular Research Center, Cincinnati, $\mathrm{OH}$, USA) according to the manufacturer's instructions and dissolved in diethyl pyrocarbonate-treated $\mathrm{H}_{2} \mathrm{O}$. All the experiments were carried out according to the guidelines of the Animal Ethics Committee of Sichuan University.

\section{Cloning of the full-length cDNA of $d P R L R$ gene from the kidneys of LF male chickens}

It has been reported that the last exon of $d P R L R$ gene is incomplete and interrupted by a 78 bp breakpoint sequence
(dSPEF2) genes arranged in an opposite direction (Elferink et al. 2008). In the $K$ allele, unlike the original $P R L R$ gene in the region adjacent to it, the $d P R L R$ gene has an incomplete last exon (named exon $16^{\prime}$ in this study), which is linked to intron 4 (in the antisense direction) of $d S P E F 2$ gene. Arrows represent the putative transcription start sites of each gene. GHR gene is located on chromosome $Z$ close to the $P R L R$ gene.

(Elferink et al. 2008), suggesting that the $d P R L R$ gene may have a $3^{\prime}$-UTR that is different from that of the original $P R L R$ gene. To determine the $3^{\prime}$-UTR sequence of $d P R L R$, gene-specific primers were designed to amplify the $3^{\prime}$-UTR of $A P R L R$ from the kidneys of 1-week-old male Lohmann chicks (with the LF phenotype) using the SMART RACE cDNA Amplification Kit according to the manufacturer's instructions (Clontech). The amplified PCR products were cloned into a pTA2 vector (Toyobo, Osaka, Japan) and sequenced using the ABI3100 Genetic Analyzer (Beijing Genomics Institute, Shanghai, China). Then, according to the cloned unique $3^{\prime}$-UTR sequence of $A P R L R$ and cDNA sequence of the original PRLR gene reported previously (Tanaka et al. 1992, Bu et al. 2013), new gene-specific primers were designed to amplify the full-length cDNA of dPRLR from chicken kidneys using high-fidelity Taq DNA polymerase (Toyobo; Table 1). The amplified PCR products were cloned into a pTA2 vector and sequenced. Finally, the full-length cDNA sequence containing an open reading frame (ORF) of the $d P R L R$ gene was determined by sequencing at least three independent clones. 
Table 1 Primers used ${ }^{\mathrm{a}}$ in the study

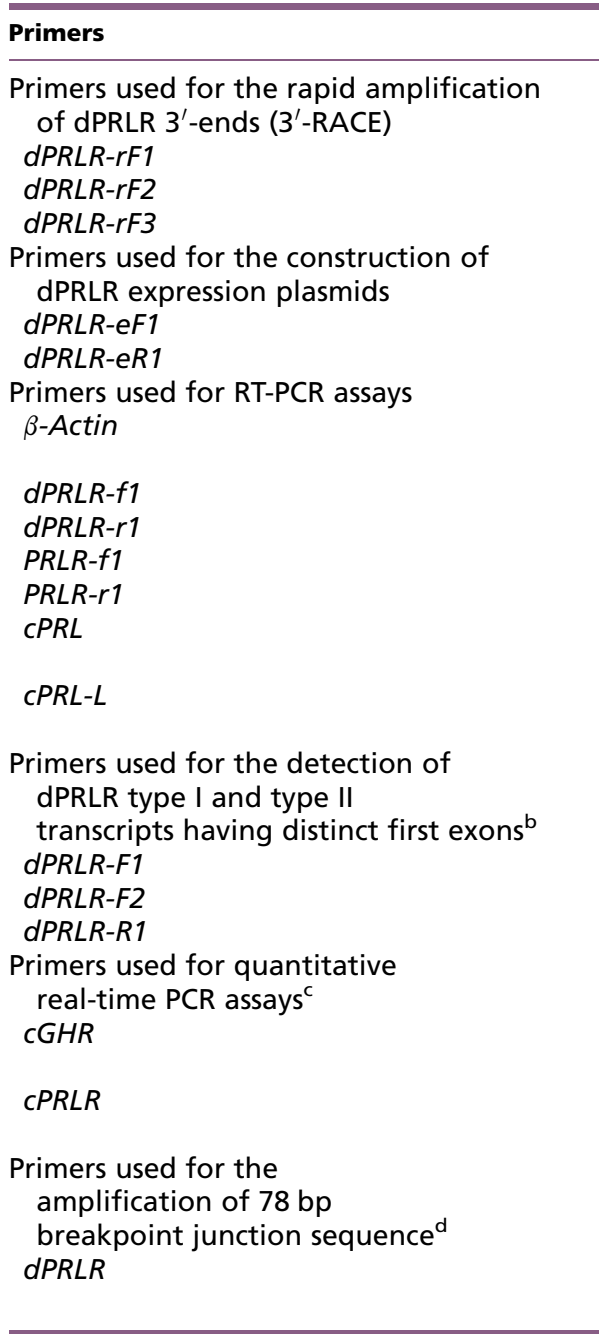

Sense/antisense

Primer sequence $\left(5^{\prime}-3^{\prime}\right)$

Size (bp)

Sense

Sense

Sense

Sense

Antisense

Sense

Antisense

Sense

Antisense

Sense

Antisense

Sense

Antisense

Sense

Antisense

Sense

Sense

Antisense

Sense

Antisense

Sense

Antisense

Sense Antisense
GCAAACCTGACCACCATGGATCATGGA

ACCGCCAGTGCCAGGGCCAAAGAT

GTTGAGTGCTCTTGGTTGCCATGGCT

CGGGGTACCAAGAGGAAGTGGAAATCATGA

ACAAGTGTCAGACTAGGGCTAGCA

TGTGCTACGTCGCACTGGAT

GCTGATCCACATCTGCTGGA

CACTGGCTGATGTCAGATCT

TCACCTGAGACCCAATGTTG

CATGGAGTGAATGGAGCTCAG

TCACAGACTTATCAGCTAGG

TCACACAGAATCCCTACCATGA

GCTCCTCAATCTCTACAGCCT

TCCACCGAGCTGGAGAAGTACT

GTCACTCATCACATTTGCTTCA

2109

401

1100

1370

472

545

CATGAATTGACATGGGTCGA

CAGTTCACCATGACTGAGAAT

ACAAGTGTCAGACTAGGGCTAGCA

2114-2760

2135-2478

CAGATACTGACAGGCTCCTGAGT

GAGATGGCATCACATGTGTCGCT

CAGCCAGATCCTCCTGTGAATGT

CTCGAGGGTAAGCCATCCCGATCT

148

126

TGAAACCATCCCTGGAGAGATG ACAAGTGTCAGACTAGGGCTAGCA
78

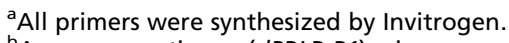

${ }^{\mathrm{b}} \mathrm{A}$ common antisense ( $\left(P R L R-R 1\right.$ ) primer was used to examine the expression of $d P R L R$ type I and type II transcripts with distinct first exons (exon $1 \mathrm{~A}^{\prime}$ or exon $1 \mathrm{G}^{\prime}$ ). Multiple bands of different sizes (Fig. 7) were detected probably due to the alternative mRNA splicing of $d P R L R$ gene in the $5^{\prime}$-UTR or coding region.

cPrimers used for evaluating the copy number of PRLR gene (GHR gene used as an internal control). The quantitative real-time PCR method was established in our previous study (Wang et al. 2007).

dPrimers were designed according to a previous report (Elferink et al. 2008).

\section{RT-PCR}

RT was carried out at $42^{\circ} \mathrm{C}$ for $2 \mathrm{~h}$ in a total volume of $10 \mu \mathrm{l}$ consisting of $2 \mu \mathrm{g}$ of total RNA collected from different tissues, $1 \times$ single strand buffer, $0.5 \mathrm{mM}$ of each deoxynucleotide triphosphate, $0.5 \mu$ g oligo-deoxythymide, and $100 \mathrm{U}$ M-MLV reverse transcriptase (Promega). All negative control reactions were carried out under the same conditions without reverse transcriptase in the reaction mixture.

According to our previously established methods (Wang \& Ge 2004, Wang et al. 2012a,b), RT-PCR assays were carried out to examine the mRNA expression of

http://jme.endocrinology-journals.org DOI: 10.1530/JME-13-0068
() 2013 Society for Endocrinology Printed in Great Britain
dPRLR, PRLR, PRL, and PRL-L genes in chicken tissues; $\beta$-actin gene was used as an internal control for monitoring RNA loading and RT efficiency. PCR was carried out under the following conditions: 2-min denaturation at $95^{\circ} \mathrm{C}$, followed by 23 cycles (for $\beta$-actin: $30 \mathrm{~s}$ at $95^{\circ} \mathrm{C}, 30 \mathrm{~s}$ at $56^{\circ} \mathrm{C}$, and $45 \mathrm{~s}$ at $72{ }^{\circ} \mathrm{C}$ ) or 33 cycles (for $d P R L R$ and $P R L R$ : $30 \mathrm{~s}$ at $95^{\circ} \mathrm{C}$ and $30 \mathrm{~s}$ at $60^{\circ} \mathrm{C}$ and 90 -s extension at $72^{\circ} \mathrm{C}$ ) or 35 cycles (for $C P R L$ and $c P R L-L: 30 \mathrm{~s}$ at $95^{\circ} \mathrm{C}$ and $30 \mathrm{~s}$ at $58^{\circ} \mathrm{C}$ and 45 -s extension at $72^{\circ} \mathrm{C}$ ) of the reaction, ending with a 5 -min extension step at $72^{\circ} \mathrm{C}$. Primers used for the RT-PCR assays are listed in Table 1. (Sense and antisense primers located on different exons were used for each

Published by Bioscientifica Ltd. 
RT-PCR assay to ensure that the PCR product was amplified from the cDNA of the target gene.) The PCR products were visualized on a u.v.-transilluminator (Bio-Rad Laboratories, Inc.) after electrophoresis on $2 \%$ agarose gel containing ethidium bromide. The identity of the PCR products was verified by sequencing (Beijing Genomics Institute).

\section{Functional characterization of dPRLR in cultured HepG2 cells}

According to the cloned cDNA sequence of $d P R L R$, genespecific primers flanking the start and stop codons were designed to amplify the ORF of $d P R L R$ from adult chicken kidneys using high-fidelity Taq DNA polymerase (Toyobo; Table 1). The amplified PCR products were cloned into a pcDNA3.1(+) vector (Invitrogen) and sequenced.

In this study, the expression plasmid encoding the original PRLR (831 amino acids, KC686695) of Lohmann chicks was also constructed and used as a positive control to test whether dPRLR is an additional functional receptor for PRL.

To test whether dPRLR is functional in vitro, human hepatocellular carcinoma (HepG2) cells expressing dPRLR were treated with recombinant chicken PRL (cPRL) prepared in our laboratory (Bu et al. 2013). Receptor activation was monitored using a $5 \times$ STAT5-Luciferase reporter system as reported previously (Cocolakis et al. 2008, Bu et al. 2013). In brief, the HepG2 cells were maintained in DMEM supplemented with 10\% (vol/vol) fetal bovine serum, $100 \mathrm{U} / \mathrm{ml}$ of penicillin $\mathrm{G}$, and $100 \mu \mathrm{g} / \mathrm{ml}$ of streptomycin (HyClone, Logan, UT, USA) in a $90 \mathrm{~cm}$ culture dish (Nunc, Rochester, NY, USA) and incubated at $37^{\circ} \mathrm{C}$ with $5 \% \mathrm{CO}_{2}$. The HepG2 cells were plated in a six-well plate at a density of $3 \times 10^{5}$ cells/well $24 \mathrm{~h}$ before transfection. A mixture containing $1000 \mathrm{ng}$ of $5 \times$ STAT5-Luciferase reporter construct (an artificial promoter construct containing five STAT5-response elements fused to the luciferase gene), $100 \mathrm{ng}$ of expression plasmid encoding pig STAT5A (Fang et al. 2012), $200 \mathrm{ng}$ of expression plasmids encoding dPRLR (or full-length PRLR) or pcDNA3.1(+) vector, and $2 \mu \mathrm{l}$ of jetPRIME was prepared in $100 \mu$ l of transfection buffer. Transfection was carried out according to the manufacturer's instructions (Polyplus-transfection SA, Illkirch, France) when the cells reached 70\% confluency. After $24 \mathrm{~h}$ of culture, the cells were subcultured in a 96-well plate at a density of $2 \times 10^{4}$ cells/well at $37^{\circ} \mathrm{C}$ for $24 \mathrm{~h}$. Then, the cells were treated with the gradient concentrations of recombinant cPRL (from $10^{-10}$ to $10^{-5} \mathrm{~g} / \mathrm{ml}$ ) and incubated for an additional $18 \mathrm{~h}$ at $37^{\circ} \mathrm{C}$. After removal of the culture medium, $50 \mu \mathrm{l}$ of $1 \times$ passive lysis buffer (Promega) were added to each well, and the luciferase activity of $15 \mu$ l of cellular lysates was measured using the Luciferase Assay Kit (Promega).

\section{Western blot analysis}

To investigate whether the activation of dPRLR can increase the levels of STAT5 tyrosine phosphorylation, HepG2 cells co-transfected with 500 ng of pig STAT5A and $500 \mathrm{ng}$ of expression plasmid encoding dPRLR or PRLR (used as a positive control) or an empty pcDNA3.1 vector were cultured for $24 \mathrm{~h}$ in a six-well plate and treated with recombinant cPRL $(300 \mathrm{ng} / \mathrm{ml})$ for $30 \mathrm{~min}$. Then, the whole-cell lysates were used to examine the phosphorylated STAT5 (Tyr ${ }^{694}$ ) using western blot analysis according to the manufacturer's instructions (Cell Signaling Technology). The levels of $\beta$-actin and total STAT5 (including STAT5A and STAT5B) proteins were also examined and used as internal controls in each experiment.

\section{Statistical analysis}

The luciferase activities in HepG2 cells treated with hormone were expressed as relative fold increase when compared with the control group treated with a hormone-free medium. The data were analyzed using one-way ANOVA followed by Dunnett's test using Graphpad Prism 4 (Graphpad Software, San Diego, CA, USA). To validate our results, all experiments were repeated at least two to four times.

\section{Results}

Cloning of the full-length CDNA of the $d P R L R$ gene from the kidneys of LF chickens

A partial duplication of the $P R L R$ gene $(d P R L R)$ with an incomplete last exon has been identified within the $K$ locus on chromosome $Z$ recently (Elferink et al. 2008; Fig. 1); however, the cDNA sequence of $d P R L R$ remains unclear. Therefore, in this study, using $3^{\prime}$-RACE PCR, we first amplified and cloned the $3^{\prime}$-UTR of $d P R L R$ from the kidneys of male Lohmann chicks carrying a $K$ allele. Sequence analysis revealed that the cloned $3^{\prime}$-UTR of dPRLR (448 bp) is different from that of the original PRLR gene (accession no.: JQ768800). Similar to the $3^{\prime}$-UTR of most eukaryotic genes, the $3^{\prime}$-UTR of $d P R L R$ also contains a consensus polyadenylation site (AAUAAA) upstream of its

Published by Bioscientifica Ltd. 
poly(A) tail (Supplementary Figure 2, see section on supplementary data given at the end of this article).

According to the 3 '-UTR sequence of $d P R L R$ and cDNA sequence of the original PRLR (Tanaka et al. 1992, Bu et al. 2013), new gene-specific primers were designed to amplify the full-length cDNA containing an ORF of $A P R L R$ from the kidneys of male chicks with a $K$ allele. The cloned $d P R L R$ was 2519 bp in length, and its nucleotide sequence was nearly identical to that of PRLR except for its 3 '-UTR (Supplementary Figure 2).

The cloned $A P R L R$ is predicted to encode a novel receptor of 683 amino acids (accession no.: JQ768801). Similar to PRLR, dPRLR has a large extracellular domain containing two putative ligand-binding domains (LBD1 and LBD2), a single TMD, and a cytoplasmic tail of 221 amino acids (Brooks 2012). Sequence alignment further showed that dPRLR shares a nearly identical amino acid sequence identity with the original PRLR cloned from the kidneys of Lohmann chicks (accession no.: KC686695), with only four amino acid substitutions being observed between the two receptors. One substitution $\left(\operatorname{Ser}^{159} \rightarrow\right.$ Asn $^{159}$ ) was observed at the extracellular LBD1, while the other three substitutions were found at the intracellular domain Pro $^{576} \rightarrow \mathrm{Ser}^{576}, \mathrm{Ser}^{628} \rightarrow \mathrm{Asn}^{628}$, and $\left.\mathrm{Glu}^{683} \rightarrow \mathrm{Ile}^{683}\right)$. In comparison with the original PRLR, dPRLR has a shorter intracellular domain and lacks a C-terminal tail of 149 amino acids. This means that there is a concurrent absence of the three tyrosine residues $\left(\mathrm{Tyr}^{717}, \mathrm{Tyr}^{755}\right.$, and $\left.\mathrm{Tyr}^{820}\right)$ on the C-terminal end, which are conserved in the PRLR of other vertebrate species, including humans, rats, mice, bullfrogs, lizards, and zebrafish (Fig. 2; Tanaka et al. 1992, Bu et al. 2013). However, a tyrosine residue at position $635\left(\mathrm{Tyr}^{635}\right)$ and Box 1 and Box 2 motifs highly conserved in vertebrate PRLR are still retained within the short C-terminus of dPRLR (Fig. 2; Bole-Feysot et al. 1998, Brooks 2012).

\section{dPRLR expressed in HepG2 cells is functionally coupled to the JAK-STAT signaling pathway}

To examine whether dPRLR is functional in vitro, HepG2 cells expressing dPRLR were treated with recombinant cPRL, and then receptor activation was monitored using a $5 \times$ STAT5-Luciferase reporter system as reported previously (Cocolakis et al. 2008, Bu et al. 2013). As shown in Fig. 3A, cPRL could stimulate the luciferase activities of HepG2 cells in a dose-dependent manner via the activation of dPRLR, indicating that dPRLR is a novel functional receptor for PRL and potentially coupled to the intracellular JAK-STAT signaling pathway. Interestingly, we also observed that the recombinant cPRL seemed to be 1.2- to 1.6-fold less potent in activating dPRLR than in activating the original chicken PRLR expressed in HepG2 cells in four independent experiments (Fig. 3A), although more assays would be required for confirmation over its statistical significance.

To further investigate whether the activation of dPRLR can increase the levels of STAT5 tyrosine phosphorylation, HepG2 cells co-transfected with dPRLR (or PRLR) were treated with cPRL for 30 min and phosphorylated STAT5 levels were examined in the whole-cell lysates using western blot analysis. As shown in Fig. 3B, similar to that of PRLR, the activation of dPRLR can increase the levels of STAT5 phosphorylation significantly. No significant change was observed in the negative control, i.e., HepG2 cells transfected with the empty pcDNA3.1 $(+)$ vector upon cPRL treatment (Fig. 3B). These findings clearly indicate that dPRLR expressed in HepG2 cells is functionally coupled to the intracellular STAT5 signaling pathway.

\section{Tissue expression of $d P R L R$ mRNA in male embryos and chickens carrying a $K$ allele}

As the first step toward unraveling the roles of $d P R L R$ gene in chickens, we used only male embryos and chickens (LF) carrying a $K$ allele (genotype $K / k+$ ) to examine and compare the tissue expression patterns of $d P R L R$ and PRLR (the original PRLR) genes in this study. As shown in Fig. 4, both $d P R L R$ and PRLR genes were detected to be co-expressed in all tissues examined, the brain, small intestine, liver, lungs, muscle, and testis of embryos (from E12 to E20) and 1-week-old chicks using RT-PCR. Similarly, both receptor genes were also found to be co-expressed in all the 12 tissues examined (the brain, heart, small intestine, kidneys, liver, lungs, muscle, testis, pituitary, spleen, pancreas, and skin) of LF male chickens at the 2-month and adult stages (Fig. 5). Interestingly, we also observed that the tissue expression patterns of the two genes ( $d P R L R$ and PRLR) appeared to be more or less similar. For instance, the relatively strong PCR signals of the two PRLR genes were consistently observed in the whole brain, small intestine, kidneys, testis, and pituitary of male chickens at the 2-month and adult stages, even though our PCR method was not quantitative (Fig. 5).

In sharp contrast, only PRLR gene was detected to be expressed in all tissues examined in EF female chickens (or embryos) with the genotype $k+/ w$ (without $d P R L R$ gene) (Figs 4 and 5).

Published by Bioscientifica Ltd. 


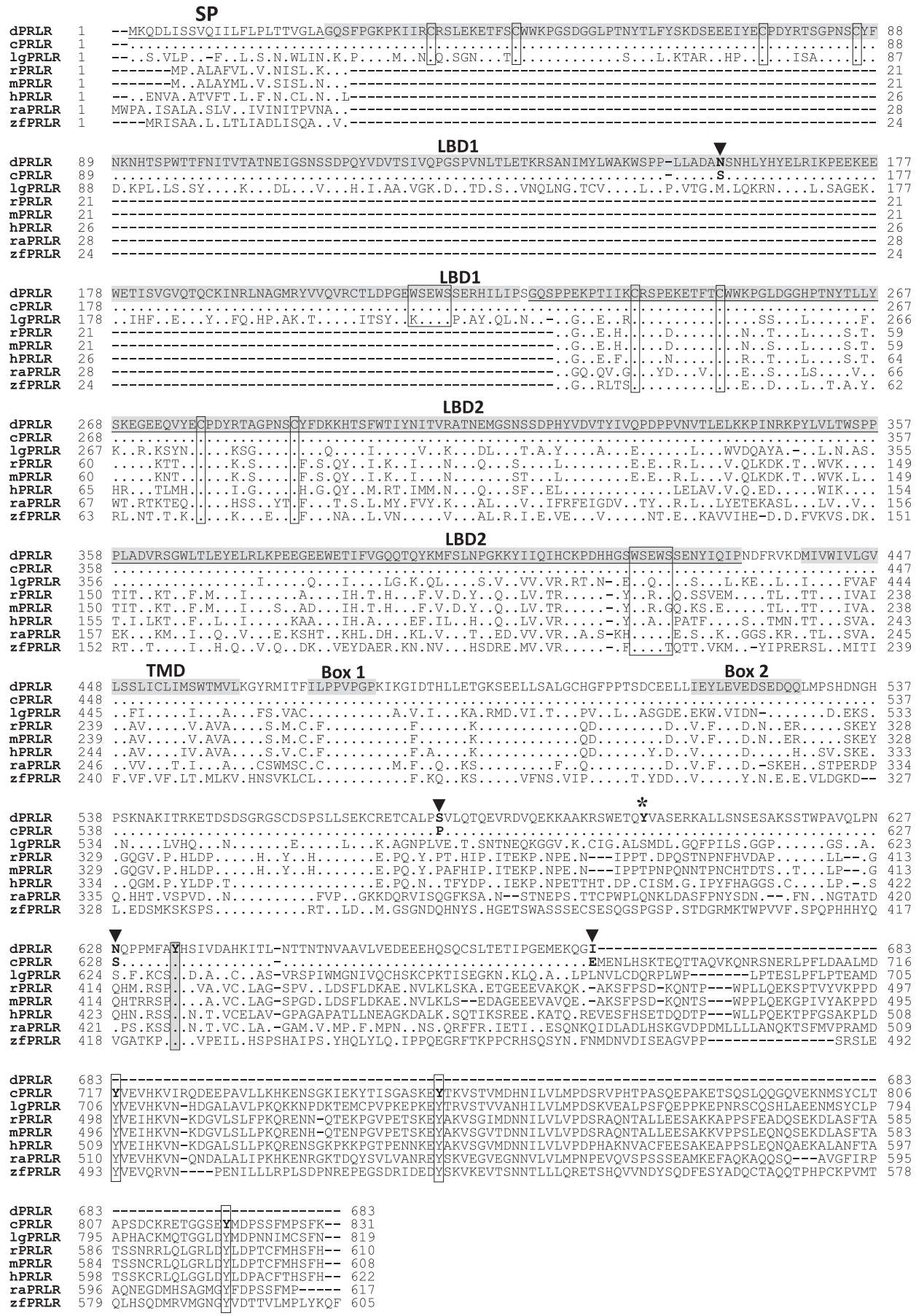

Figure 2

Amino acid sequence alignment of the duplicated PRLR (dPRLR: JQ768801, 683 amino acids) with chicken PRLR derived from the original PRLR gene (cPRLR: KC686695, 831 amino acids, cloned from the kidneys of Lohmann chickens) and PRLR from other vertebrate species including leopard geckos (IgPRLR: BAD24103), rats (rPRLR: NP_001029283), mice (mPRLR: NP_035299), humans (hPRLR: NP_000940), bullfrogs (raPRLR: BAD14941), and zebrafish (zfPRLR: NP 001122149). Arrowheads indicate the four amino acid substitutions (in bold) observed between dPRLR and the original PRLR. Signal peptide (SP) is underlined; LBD1 is shaded; LBD2 is shaded and underlined; TMD, Box 1 motif, and Box 2 motif are shaded. The tyrosine residue at position 635 ( $\mathrm{Tyr}^{635}$ of CPRLR) conserved in chickens and other species is boxed and shaded. The other three conserved tyrosine residues ( $\mathrm{Tyr}^{717}$, $\mathrm{Tyr}^{755}$, and $\mathrm{Tyr}^{820}$ of CPRLR) absent in dPRLR are boxed. Asterisk $\left(^{*}\right)$ indicates an extra tyrosine residue at position $600\left(\mathrm{Tyr}^{600}\right.$, in bold) only observed in chicken $\mathrm{PPRLR}$ and PRLR. The conserved cysteine residues and WSXWS motif(s) at the extracellular LBD(s) critical for receptor folding, trafficking, and activation are also boxed (Brooks 2012).

Published by Bioscientifica Ltd 
A

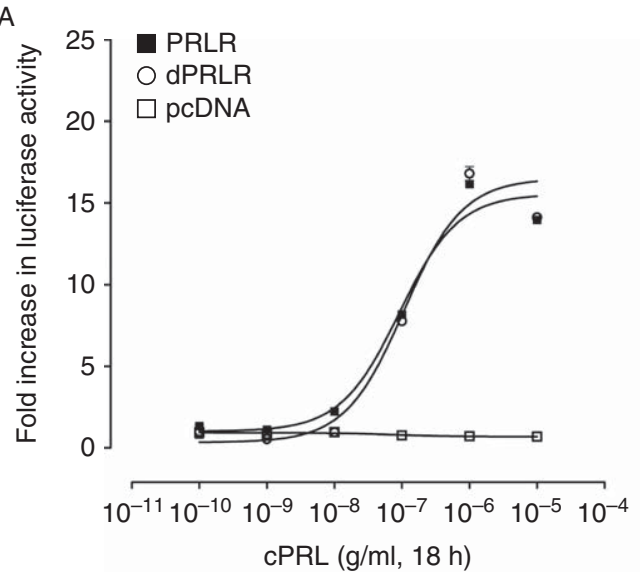

B
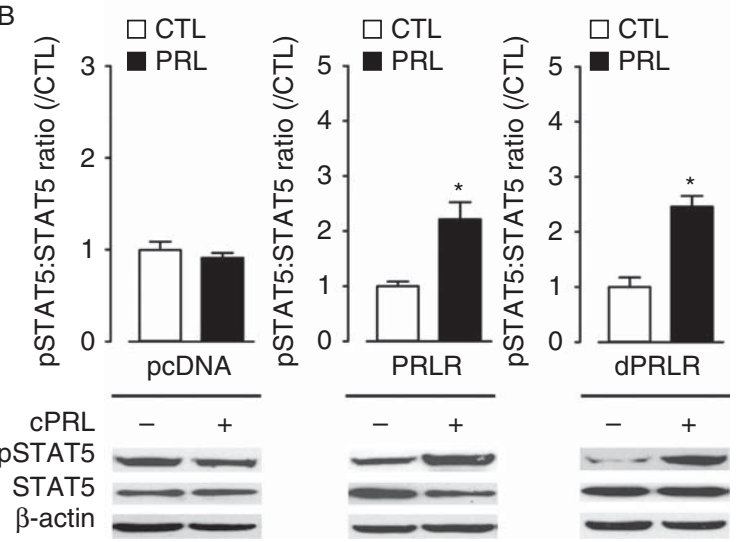

Figure 3

(A) Activation of chicken dPRLR and PRLR expressed in HepG2 cells by recombinant CPRL treatment $\left(10^{-10}\right.$ to $\left.10^{-5} \mathrm{~g} / \mathrm{ml}, 18 \mathrm{~h}\right)$. A $5 \times$ STAT5Luciferase reporter system was used to monitor receptor activation by co-transfection of a $5 \times$ STAT5-Luciferase reporter construct, pig STAT5A, and receptor expression plasmid in cultured HepG2 cells; co-transfection of an empty pcDNA3.1 $(+)$ vector, pig STAT5A, and a $5 \times$ STAT5-Luciferase reporter construct in HepG2 cells was used as an internal control. Each data point represents mean \pm s.E.M. of three replicas. (B) CPRL enhances STAT5 tyrosine phosphorylation of HepG2 cells expressing either dPRLR or chicken PRLR. HepG2 cells transiently expressing chicken PRLR or dPRLR (empty pcDNA3.1(+) vector used as a negative control) were treated with recombinant chicken prolactin (cPRL, $300 \mathrm{ng} / \mathrm{ml}$ ) for $30 \mathrm{~min}$ and total cell lysates were analyzed by western blot assays using specific antibodies against phosphorylated STAT5 (pSTAT5), STAT5 (total STAT5), and $\beta$-actin (loading control). Phosphorylated and total STAT5 levels were determined using densitometric analysis, and STAT5 phosphorylation was expressed as relative fold increase in phosphorylated/total STAT5 levels vs respective control (CTL). Each data point represents mean + S.E.M. of three replicas. ${ }^{*} P<0.01$ vs respective control. Representative western blots (pSTAT5, upper panel; total STAT5, middle panel; and $\beta$-actin, lower panel) are shown at the bottom of each graph.

\section{Expression of $d P R L R, C P R L R, C P R L$, and $C P R L-L$ mRNAs in chicken skin tissue}

Since $d P R L R$ is probably a candidate gene associated with LF phenotype (Elferink et al. 2008, Wang et al. 2010a, Luo et al. 2012), using RT-PCR, we also examined the expression of its mRNA in the skin of male chickens (with the genotype $K / k+$ ) at different developmental stages. As shown in Figs 5 and 6, both $d P R L R$ and $P R L R$ genes were detected to be co-expressed not only in the skin of male embryos from E12 to E20, but also in the skin tissue of 1-week-old, 2-month-old, and adult male chickens.

By contrast, only the PRLR gene was detected to be expressed in the skin tissue of females with the genotype $k+/ w$ at various stages, i.e., from E12 to the adult stage (Figs 5 and 6).

To determine whether the two PRLR ligands, PRL and PRL-L, could be produced locally (Wang et al. 2010b, Bu et al. 2013), the mRNA expression of $c P R L$ and $C P R L-L$ genes was also examined in the skin tissue of both sexes at different developmental stages, i.e., from E12 to the post-hatching stage (1 week), using RT-PCR. As shown in Fig. 6, an apparent PCR signal of $P R L$ was consistently observed in the skin tissue of both male (genotype $K / k+$ ) and female (genotype $k+/ w$ ) embryos at E20 and only a weak PCR signal was detected in the skin tissue of 1-week-old male and female chicks, whereas no PCR signal was detected at other stages. Unlike that of $C P R L$, only an extremely faint PCR signal of $C P R L-L$ was observed in the skin tissue of both sexes at all the stages examined.

\section{Expression of dPRLR type I and type II transcripts with distinct first exons in LF chicken tissues}

In our recent study, we reported that chicken PRLR transcripts encoding PRLR (831 amino acids) should be subdivided into two types, type I and type II transcripts, according to the first exon (exon $1 \mathrm{G}$ or exon $1 \mathrm{~A}$ ) used in their 5'-UTRs (Bu et al. 2013). PRLR type I transcripts use exon $1 \mathrm{G}$ as their first exon, the expression of which is driven by $P 1$ promoter, whereas $P R L R$ type II transcripts use exon $1 \mathrm{~A}$ as their first exon and their expression is controlled by $P 2$ promoter (Fig. 7A; Bu et al. 2013). These findings led us to speculate that $d P R L R$ gene could also produce two types of transcripts in chicken tissues similar to those produced by the original PRLR gene. To test this possibility, using a sense primer located on exon 1A (primer F1) or on exon $1 \mathrm{G}$ (primer F2) and an antisense primer (primer R1) specific to the unique $3^{\prime}$-UTR of $d P R L R$ gene (Fig. 7A and Table 1), we carried out an RT-PCR to examine their existence in the small intestine and kidneys of male LF chicks. As shown in Fig. 7B and C, the PCR bands of expected sizes could be amplified from the two tissues examined, and sequence analyses further confirmed the existence of $d P R L R$ type I and type II transcripts with distinct first exons in their $5^{\prime}$-UTRs. This finding not only indicates that, similar to the $P R L R$ gene, the $d P R L R$ gene could also generate type I and type II

Published by Bioscientifica Ltd. 


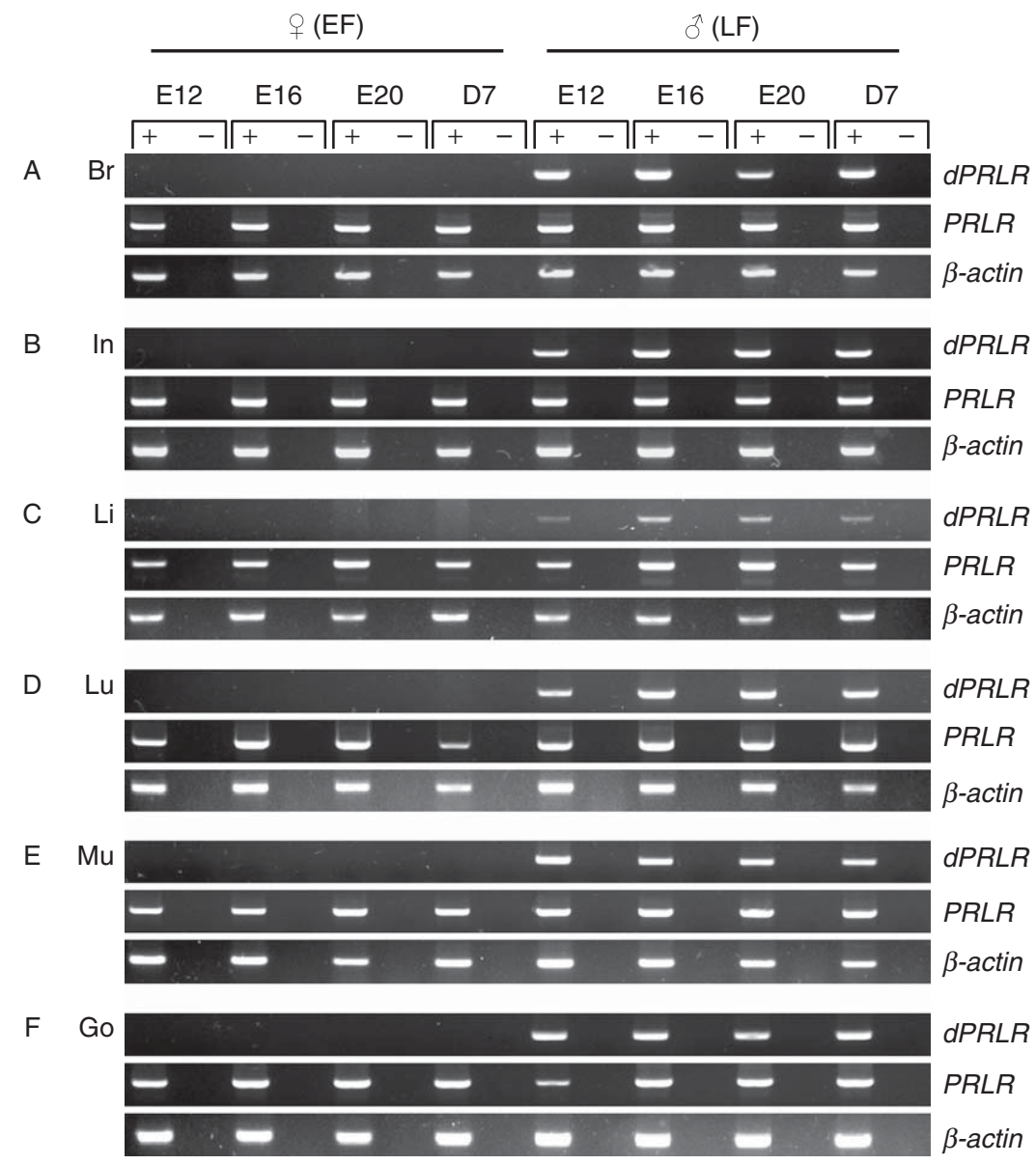

Figure 4

RT-PCR detection of the expression of $d P R L R$ and PRLR mRNAs in different tissues of developing embryos from E12 to E20 and 7-day-old (D7) chicks: (A) whole brain (Br); (B) small intestine (In); (C) liver (Li); (D) lung (Lu); (E) muscle $(\mathrm{Mu})$; (F) gonads (Go; ovaries from female embryos or chicks or testis from male embryos or chicks). Both $d P R L R$ gene and the original PRLR gene were detected to be co-expressed in all the tissues of male chicks $(\delta, L F)$ and embryos with the genotype $K / k+$. By contrast, only the original $P R L R$ gene was detected to be expressed in all the tissues of female chicks

transcripts in chicken tissues, which use the duplicated exon $1 \mathrm{G}$ and exon $1 \mathrm{~A}$ (named exon $1 \mathrm{G}^{\prime}$ and exon $1 \mathrm{~A}^{\prime}$ in this study) as their first exons respectively, but also implies that the expression of $d P R L R$ type I and type II transcripts is controlled by two functional promoters, designed as $P 1^{\prime}$ and $P 2^{\prime}$ promoters in this study, which were also duplicated from the original PRLR gene (Fig. 7A; Bu et al. 2013).

\section{Discussion}

This study provides clear evidence that $d P R L R$ at the sexlinked LF $K$ locus of chickens is widely expressed in all tissues examined, including the skin, with a spatiotemporal expression pattern more or less similar to that of the original
( $q$, early-feathering) and embryos with the genotype $k+/ W$. No PCR signal was detected in all the negative controls $(-)$. Since $d P R L R$ and PRLR mRNAs differ in their $3^{\prime}$-UTRs, a sense primer $(r 1)$ located on the coding region and an antisense primer ( $\mathrm{r} 1$ ) specific either to $d P R L R 3^{\prime}$-UTR or to PRLR $3^{\prime}$-UTR were designed for RT-PCR detection of the expression of $d P R L R$ and $P R L R$ in chicken tissues (Figs 4, 5 and 6). The location of the primers used for PRLR (PRLR-f1/r1) and $d P R L R(d P R L R-\mathrm{f} 1 / \mathrm{r} 1)$ is shown in Fig. 7A.

copy of the PRLR gene localized in the region adjacent to it. Furthermore, we demonstrated that the $A P R L R$ gene is likely to encode a novel receptor for PRL. To our knowledge, this study represents the first to report the structure, functionality, and spatiotemporal expression of the $d P R L R$ gene in LF chickens and sets an initial, nonetheless important, step toward uncovering the roles of the $A P R L R$ gene in chickens carrying the $K$ allele.

\section{Gene structure of the $d P R L R$ gene at the sex-linked LF $K$ locus}

In this study, we first cloned the cDNA sequence containing an ORF of $d P R L R$ from the kidneys of male

Published by Bioscientifica Ltd. 
A 2-Month-old

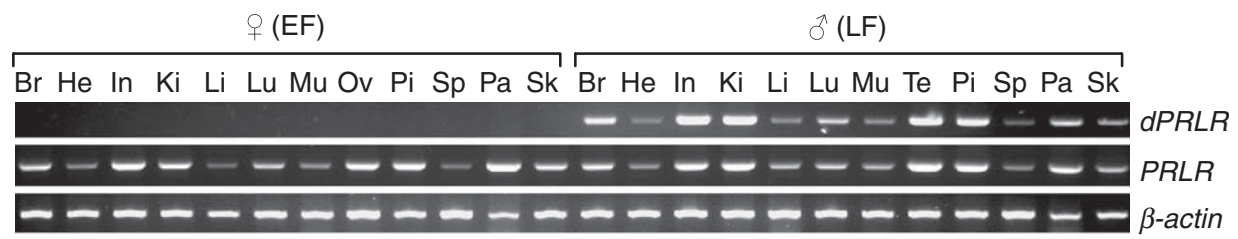

B Adult

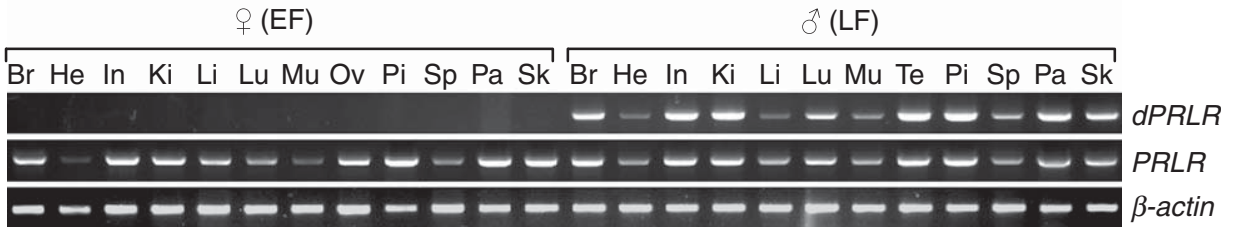

\section{Figure 5}

RT-PCR detection of the expression of $d P R L R$ and PRLR mRNAs in different tissues (brain $(\mathrm{Br})$, heart $(\mathrm{He})$, small intestine $(\mathrm{In})$, kidney $(\mathrm{Ki})$, liver (Li), lung $(\mathrm{Lu})$, muscle $(\mathrm{Mu})$, ovary $(\mathrm{Ov})$, testis $(\mathrm{Te})$, pituitary $(\mathrm{Pi})$, spleen $(\mathrm{Sp})$, pancreas $(\mathrm{Pa})$, and skin $(\mathrm{Sk}))$ of 2-month-old $(\mathrm{A})$ and adult (B) chickens. Both $d P R L R$

chicks with a $K$ allele. Sequence analysis showed that the coding region sequence of $d P R L R$ was nearly identical to that of the PRLR gene, except for several nucleotide differences, resulting in only four amino acid substitutions being observed between APRLR and PRLR, indicating that the coding region of $d P R L R$ gene has an exon-intron organization identical to that of the original PRLR gene (Fig. 7A; Tanaka et al. 1992, Elferink et al. 2008, Bu et al. 2013). Moreover, $d P R L R$ has a spatiotemporal expression pattern more or less similar to that of the PRLR gene, suggesting that the promoter regions driving the expression of $d P R L R$ have also been duplicated from the PRLR gene (Fig. 7A; Bu et al. 2013). and PRLR genes were detected to be co-expressed in all the tissues of male chickens ( ${ }^{\prime}, L F$, genotype $K / k+$ ) carrying a $K$ allele. By contrast, only the original $P R L R$ gene was detected to be expressed in all the tissues of female chickens ( $($, EF, genotype $k+/ W$ ) without the $K$ allele.

The only obvious difference observed between $d P R L R$ and PRLR lies in their $3^{\prime}$-UTRs. It has been reported that the last exon of the $d P R L R$ gene is incomplete and interrupted by a 78 bp breakpoint junction fragment, which links to intron 4 of the partially duplicated SPEF2 gene (dSPEF2) (Fig. 1; Elferink et al. 2008). Consistent with this finding, the unique 3'-UTR of the $A P R L R$ gene also contains a 78 bp breakpoint junction fragment and a $409 \mathrm{bp}$ sequence antisense to the partial sequence of intron 4 of $d S P E F 2$ gene (Supplementary Figure 2). The identification of this unique $3^{\prime}$-UTR of $d P R L R$ also provides us with an important and valuable molecular marker to detect the existence and mRNA expression of the $d P R L R$ gene in chicken strains with the LF phenotype.

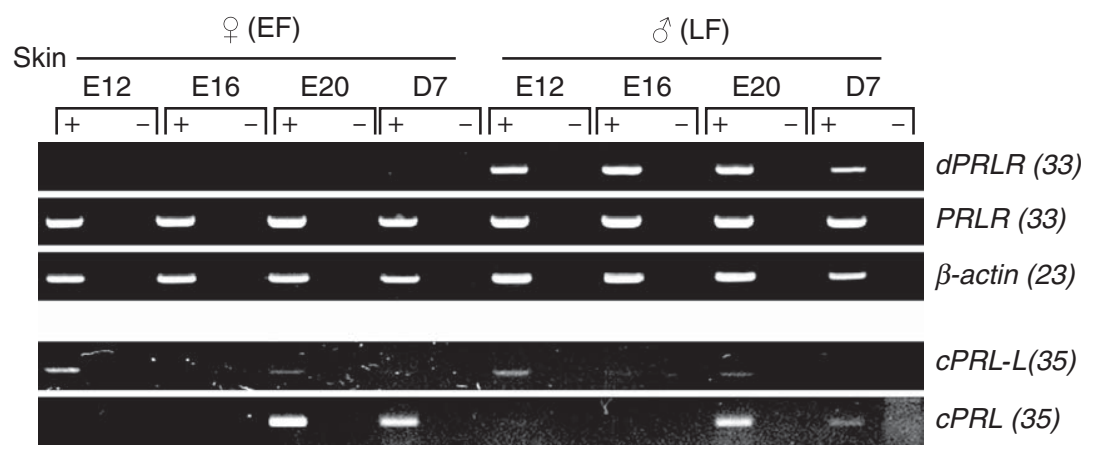

\section{Figure 6}

RT-PCR detection of the expression of $d P R L R, P R L R, C P R L-L$, and $C P R L$ mRNAs in the skin tissue of developing embryos (from E12 to E20) and 7-day-old (D7) chicks. Both $d P R L R$ gene and the original PRLR gene were detected to be co-expressed in the skin of male chicks $(\delta, L F)$ and embryos with the

http://jme.endocrinology-journals.org DOI: 10.1530/JME-13-0068
C 2013 Society for Endocrinology Printed in Great Britain genotype $K / k+$. By contrast, only the original $P R L R$ gene was detected to be expressed in the skin of female chicks (ㅇ, EF) and embryos with the genotype $k+/ w$. The number in brackets indicates the number of PCR cycles used. No PCR signal was detected in all the negative controls (-).

Published by Bioscientifica Ltd. 
A
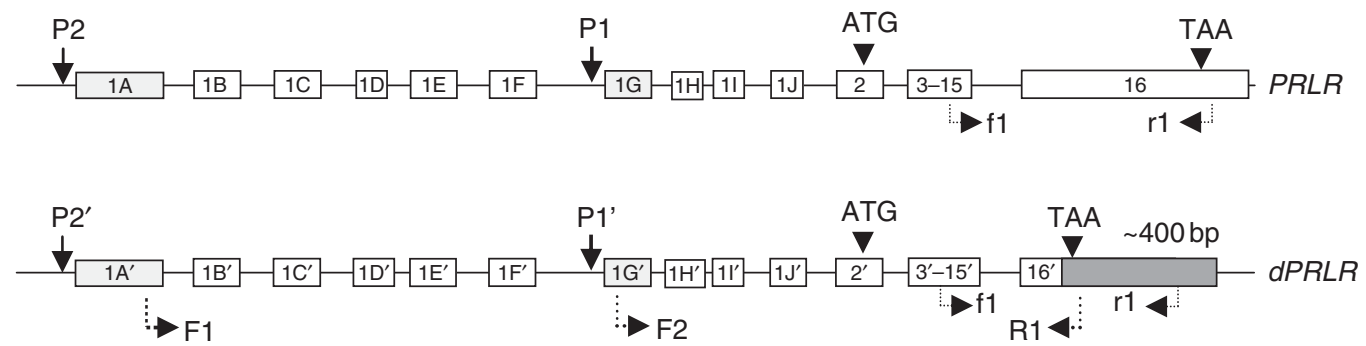

B $d P R L R$ type I transcripts

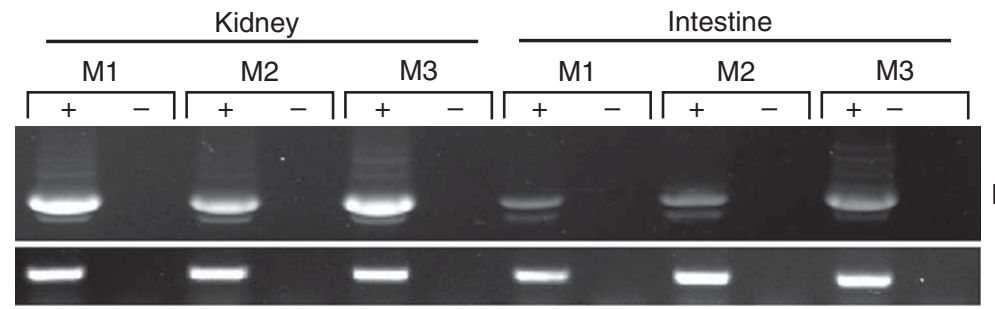

F2/R1 (33)

$\beta$-actin (23)

C $d P R L R$ type II transcripts

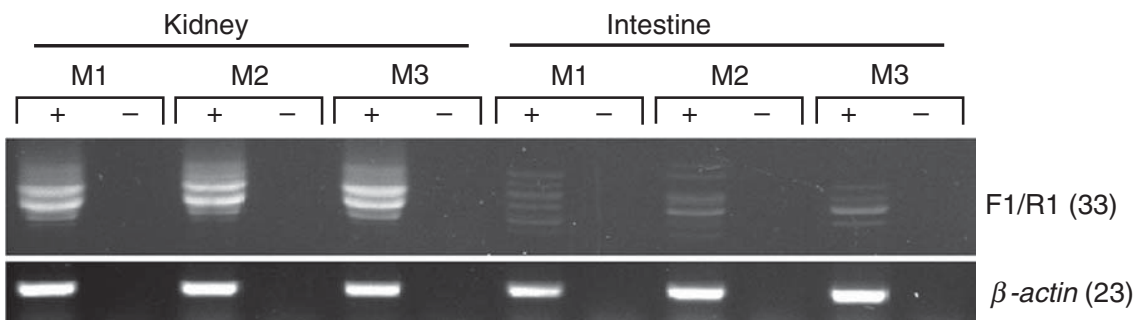

\section{Figure 7}

(A) Schematic diagram showing the putative promoters and exon organization of $d P R L R$ and $P R L R$ genes in LF chickens. The original PRLR gene consists of at least 25 exons, including ten non-coding exons (exon $1 \mathrm{~A}$ to exon $1 \mathrm{~J}$ ) upstream of the translation start site (ATG) and 15 exons (exons 2-16) within the coding region (Bu et al. 2013). The two promoters near exon $1 \mathrm{G}$ (promoter 1, P1) and exon 1A (promoter 2, P2) are responsible for the expression of $P R L R$ type I and type II transcripts respectively in chickens (for detailed information on CPRLR, refer to Bu et al. (2013)). dPRLR gene has been proposed to be duplicated from the original $P R L R$ gene and thus may have a structure identical to that of $P R L R$ gene (including two promoters $\left(P 1^{\prime}\right.$ and $P 2^{\prime}$ ) and 25 exons (exon $1 A^{\prime}$ to exon $\left.16^{\prime}\right)$ ), except the $3^{\prime}$-region of the last exon (exon 16') (shaded) of $d P R L R$ is distinct from that of $P R L R$ gene. Similar to those of $P R L R$ gene, the $P 1^{\prime}$ promoter (near exon $1 \mathrm{G}^{\prime}$ ) and $P 2^{\prime}$ promoter (near exon $1 A^{\prime}$ ) of the $d P R L R$ gene are probably responsible for the expression of $d P R L R$ type I and type II transcripts respectively in LF chicken

\section{The $d P R L R$ gene may encode a novel functional PRLR}

In this study, we found that $d P R L R$ is likely to encode a receptor of 683 amino acids. Compared with the original PRLR, dPRLR lacks a stretch of 149 amino acid residues including three tyrosine residues $\left(\mathrm{Tyr}^{717}, \mathrm{Tyr}^{755}\right.$, and $\mathrm{Tyr}^{820}$ ) conserved in the PRLR of vertebrate species (Bole-Feysot et al. 1998, Brooks 2012). In rats, these conserved tyrosine residues $\left(\mathrm{Tyr}^{479}, \mathrm{Tyr}^{515}\right.$, and $\mathrm{Tyr}^{580}$ in rat PRLR), particularly the last $\left(\mathrm{Tyr}^{580}\right)$, of PRLR have been tissues. Arrowheads indicate the locations of translation start codon (ATG) and stop codon (TAA) of PRLR and dPRLR. (B) RT-PCR detection of the expression of $d P R L R$ type I transcripts with exon $1 \mathrm{G}^{\prime}$ in the kidneys and small intestine of three LF male chicks (M1, M2, and M3). The location of primers F2 and R1 used is shown in Fig. 7A. (C) RT-PCR detection of the expression of dPRLR type II transcripts with an alternative first exon (exon $1 \mathrm{~A}^{\prime}$ ) in the kidneys and small intestine of three LF male chicks (M1, M2, and M3). The location of primers $\mathrm{F} 1$ and R1 used is shown in Fig. 7A. Multiple PCR bands can be observed in (B) and (C), suggesting that the complex alternative mRNA splicing also occurs within the $5^{\prime}$-UTR or coding region of the $d P R L R$ gene, as has been observed in the original PRLR gene (Bu et al. 2013). No PCR band was detected in all the negative controls $(-)$. Note: the location of the primers used for RT-PCR detection of the expression of PRLR (PRLR- $\mathrm{f} 1 / \mathrm{r} 1)$ and $d P R L R(d P R L R-f 1 / r 1)$ mRNAs (Figs 4, 5, and 6) in different chicken tissues is also shown in Fig. 7A.

reported to be responsible for JAK2-mediated receptor tyrosine phosphorylation (Lebrun et al. 1995, Pezet et al. 1997, Bole-Feysot et al. 1998), which have been proposed to be the docking sites for STAT5 signaling molecules, thereby allowing them to be phosphorylated by JAK2 kinase (Pezet et al. 1997). However, our functional study on dPRLR clearly indicated that the absence of these conserved tyrosine residues could affect neither receptor-mediated STAT5 tyrosine phosphorylation nor PRL-induced gene

Published by Bioscientifica Ltd. 
promoter activity, suggesting that dPRLR is a novel functional receptor for PRL. Our finding is partially consistent with the findings in rats and rabbits, in which the removal of the C-terminal portion or mutation of these tyrosine residues of the long-form PRLR does not inhibit PRL-stimulated STAT5 tyrosine phosphorylation (Goupille et al. 1997, Pezet et al. 1997). Since dPRLR still retains a tyrosine residue at position $635\left(\mathrm{Tyr}^{635}\right)$ conserved in all the vertebrates and an additional tyrosine residue at position $600\left(\mathrm{Tyr}^{600}\right)$ at its intracellular domain, it is possible that dPRLR may be phosphorylated at these specific site(s) and thus be capable of transmitting signals.

\section{Wide expression of $d P R L R$ gene in various tissues: implications for its potential diverse actions in LF chickens}

It has been reported that PRLR is widely expressed in various tissues of chickens (Tanaka et al. 1992, Ohkubo et al. 1998a,b). In our recent study, we further confirmed this finding and pointed out that the transcription of $P R L R$ gene is most probably controlled by multiple promoters, including a tissue-specific promoter ( $P 1$ promoter) and a generic promoter ( $P 2$ promoter) located upstream of the translation start site (Fig. 7A; Bu et al. 2013). In this study, we also showed that similar to the PRLR gene, the $d P R L R$ gene is widely expressed in all chicken tissues examined and its expression is also probably controlled by multiple promoters, including $P 1^{\prime}$ and $P 2^{\prime}$ promoters, which were duplicated from the original PRLR gene (Fig. 7).

The overlapping mRNA expression of $d P R L R$ and $P R L R$ genes in all tissues examined of LF chickens and their similar transcriptional regulatory mechanisms suggest that both the receptors are expressed and may function simultaneously in all the chicken tissues. Moreover, the wide tissue expression of $A P R L R$ also strongly suggests that dPRLR may be not only involved in feather development (Elferink et al. 2008), but also may participate in other physiological processes by mediating the diverse actions of PRL and thereby control other phenotypic traits of chickens carrying the $K$ allele.

\section{Potential association of the dPRLR gene with the LF development of chickens}

The LF phenotype of chicks has long been reported to be controlled by the $K$ locus on chromosome Z (Iraqi \& Smith 1995). Chicks with the $K$ allele (genotypes $K / w, K / K$, and $K / k+$ ) often display a LF phenotype, while chicks with the genotypes $k+/ k+$ and $k+/ w$ exhibit an EF phenotype at hatching. Since its discovery in chickens in 1922, the
$K$ locus has been introduced into some chicken breeds and widely used for gender identification of newly hatched chicks in the poultry industry (Serebrovsky 1922). For instance, in commercial crosses of egg layers, LF females $(K / w)$ are mated with homozygous EF males $(k+/ k+)$ to generate offspring, among which all males (genotype $K / k+$ ) have the LF phenotype and all females (genotype $k+/ w$ ) have the EF phenotype; thus, both sexes of chicks could be easily identified according to the developmental status of flight feathers (Fig. 1). Recently, the $K$ allele on chromosome $\mathrm{Z}$ has been reported to arise from a tandem duplication of a large fragment of $176 \mathrm{~kb}$, which contains two partially duplicated genes: $d P R L R$ and $A S P E F 2$ (Iraqi \& Smith 1995, Elferink et al. 2008). In that study, the authors proposed that $A P R L R$ is probably a candidate gene involved in the delay of feather growth (Elferink et al. 2008). However, whether $d P R L R$ gene could be expressed in chicken tissues including the skin and how it is involved in feather development remain unclear.

In this study, both $d P R L R$ and $P R L R$ genes were detected to be co-expressed in the skin tissue of LF male chickens at different developmental stages, i.e., from E12 to the adult stage. This finding, together with the evidence showing that dPRLR is functional in vitro, led us to speculate that the co-expression of dPRLR and PRLR in chicken tissues may increase the receptor numbers in target cell membranes and consequently modify the responsiveness of skin (or feather follicles) to PRL, thereby regulating LF development.

Although both dPRLR and PRLR have been shown to be functional in terms of their capability to activate the JAK-STAT signaling pathway, it should be noted that the two receptors differ significantly in their intracellular domains (Fig. 2). Thus, the possibility that the specific signaling event(s) triggered (or interfered) by dPRLR may affect feather growth cannot be ruled out completely. Regardless of the hypothetical model that is the best to explain the in vivo situation, the co-expression of dPRLR and PRLR in skin tissue hints that both the receptors are probably involved in the LF development of chicks (or embryos). Future study on the mRNA and/or protein localization of PRLR and dPRLR in skin tissue, particularly their precise localization in feather follicles, will enrich our hypotheses.

Using the transplantation of chicken skin with distinct feathering speed, Danforth (1929) reported that the feathering speed of transplanted skin from newly hatched chicks is primarily determined by the transplanted skin itself, but not by the surrounding host skin or hormones from host chicks, suggesting that the sex-linked

Published by Bioscientifica Ltd. 
gene(s) responsible for the slow-feathering act locally in the skin or feather follicles rather than through the intermediation of gonadal or other hormones (Danforth 1929). Clearly, sex-linked $d P R L R$ and PRLR genes co-expressed in the skin of slow-feathering chicks (or embryos) exactly meet the criterion.

The co-expression of PRLR and dPRLR in the skin tissue of LF chicks (or embryos) also raises an interesting issue as to where its ligand(s) comes from. It has been reported that pituitary lactotrophs begin to differentiate at E17 and secrete PRL into the blood and thus plasma PRL levels increase significantly in embryos at hatching (Harvey et al. 1979, Woods \& Porter 1998, Fu \& Porter 2004), supporting that plasma is probably a major source of PRL. Interestingly, the mRNA expression of $P R L$ and $P R L-L$, both of which have been demonstrated to be the functional ligands of cPRLR in our recent study (Bu et al. 2013), could be detected in the skin tissue of embryos or chicks. Particularly, an apparent PCR signal of PRL, instead of that of PRL-L, was consistently observed in the skin of embryos at E20 and 1-week-old chicks. Our observation is consistent with the findings in humans and mice, in which the mRNA or protein of PRL, a newly defined hair growth-inhibitory hormone, is most prominently found in the hair follicle (Craven et al. 2001, Foitzik et al. 2003, 2006, Langan et al. 2010, Ramot et al. 2010). Our findings suggest that as in mammals (Foitzik et al. 2009), skin tissue is an extra source of PRL in birds. Presumably, plasma PRL, perhaps together with PRL produced locally, may activate dPRLR and PRLR co-expressed in the skin (or feather follicles) and thus regulate feathering speed at the late embryonic and early post-hatching stages (Fig. 8).

The tandem duplication of a $176 \mathrm{~kb}$ fragment at the $K$ locus causes $d P R L R$ and $A S P E F 2$ genes to link together at their $3^{\prime}$-regions (Fig. 1), also pointing out the possibility that the mRNA transcripts of the two duplicated genes may contain antisense sequences of the other gene (PRLR or SPEF2) and may lead to RNA interference and possibly influence the translation of both the duplicated and original genes and thereby control feather development (Elferink et al. 2008). However, using 3'-RACE assays, we found that $A P R L R$ cDNA cloned from the kidneys does not contain the antisense sequence of the SPEF2 gene. Similarly, the cDNA sequence of $A S P E F 2$ obtained from LF chicken intestine contains no antisense sequence of the PRLR gene (data not shown). Moreover, Luo et al. (2012) reported that the expression levels of $P R L R$ mRNA in the skin tissue of slow-feathering chicks are 1.78-fold higher, but not lower, than those in EF chicks. These findings cast doubt on whether RNA interference could occur and
A

EF chickens
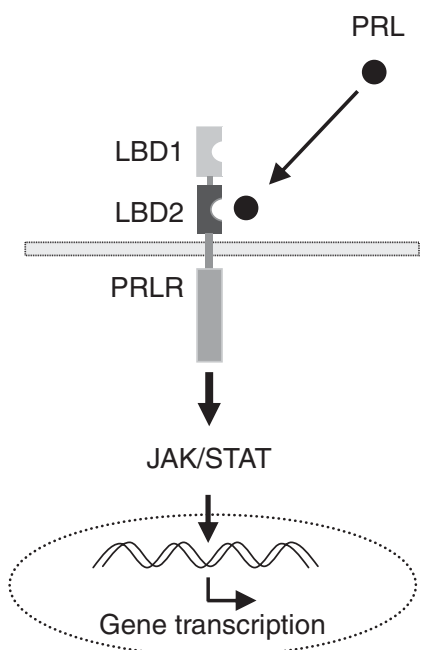

B LF chickens
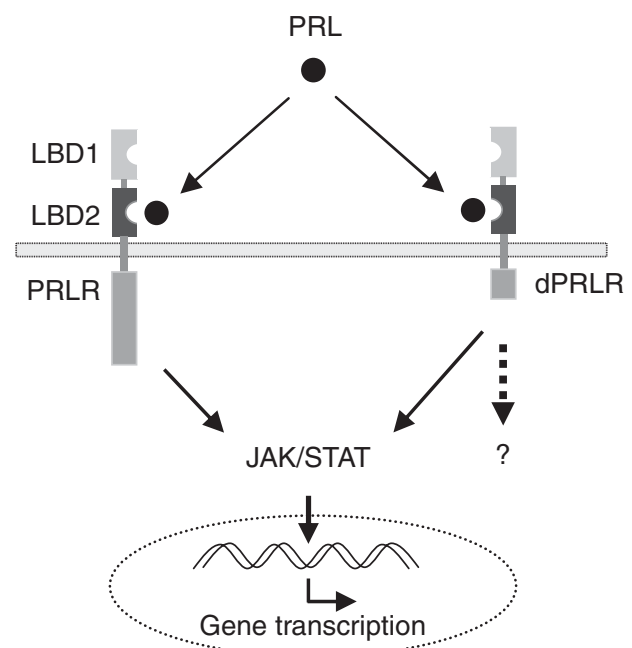

Figure 8

Hypothetical models for the roles of PRLR or dPRLR in the mediation of PRL actions in chickens with different feathering phenotypes.

(A) In EF chickens without the $K$ allele, only $P R L R$ is widely expressed in all tissues, and thus the diverse actions of PRL including its potential action on feather development are mediated by a single PRLR via interaction with its membrane-proximal LBD2 (Bu et al. 2013). (B) In LF chickens carrying the $K$ allele, both $d P R L R$ and $P R L R$ are co-expressed in all tissues examined including the skin, and thus the diverse actions of PRL in various tissues may be mediated by two PRLRs: PRLR and dPRLR, both of which were shown to be functionally coupled to the intracellular JAK-STAT signaling pathway in vitro. In LF chicks, the co-expression of PRLR and $d P R L R$ in skin tissue suggests that both the receptors might be involved in the regulation of feather development through the mediation of the actions of PRL either from plasma or produced from skin tissue. However, this hypothesis needs further verification. 
effectively regulate the mRNA levels of $P R L R$ gene in skin tissue. Clearly, future studies on the two duplicated genes (dPRLR and dSPEF2), particularly on their mRNA sequences, mRNA localization, and protein levels in feather follicles of newly hatched chicks (or embryos), will provide more clues to whether RNA interference could play a substantial role in LF development.

It has been reported that in addition to being associated with LF development, the $K$ allele is associated with other effects, such as reduction of egg production and increasing the mortality rate (Somes 1975, Harris et al. 1984, Dunnington et al. 1986, Smith \& Fadly 1988, O'Sullivan et al. 1991). Some adverse effects are probably associated with the presence of the endogenous retrovirus 21 (ev21) gene; our preliminary study $(\mathrm{G} \mathrm{Bu}, \mathrm{G}$ Huang, $\mathrm{H} \mathrm{Fu}, \mathrm{J} \mathrm{Li}$, S Huang \& Y Wang, unpublished observations) demonstrated that ev21 is likely to be located in the first intron of the $\operatorname{APRLR}$ (or PRLR) gene, at the $K$ locus in LF chickens (Bacon et al. 1988, Smith \& Fadly 1988, Boulliou et al. 1992), while some negative side effects can be attributed to the presence and expression of $A P R L R$ gene according to the findings of previous studies and the present study (Elferink et al. 2008, Wang et al. 2010a). In view of the fact that $d P R L R$ is widely expressed in all tissues examined and PRL plays critical roles in a number of physiological processes of chickens, such as the initiation and maintenance of incubation behavior, egg-laying, metabolism, and regulation of hypothalamic-pituitary-gonadal axis (Sharp et al. 1988, 1998, Talbot et al. 1991), it is tempting to speculate that similar to PRLR, dPRLR is capable of mediating the diverse actions of PRL in vivo and thus may also affect other phenotypic traits of chickens (Fig. 8). Clearly, more studies are required to fully uncover the roles of $A P R L R$ in chickens, including i) extensive studies on mRNA and protein levels of dPRLR (and PRLR) gene in various tissues at different developmental stages in both sexes of chickens with distinct genotypes $(K / K, K / k+, k+/ k+, K / w$, and $k+/ w)$; ii) intensive studies on the intracellular signaling event(s) triggered (or interfered) by dPRLR; and iii) extensive investigations on the coordinated actions of dPRLR and PRLR and their ligand(s) in the control of the physiological processes and phenotypic traits of chickens. Undoubtedly, these systematic studies will help us to re-evaluate whether it is necessary to introduce the $K$ allele into some chicken strains from a whole new perspective.

In summary, $d P R L R$ gene within the $\mathrm{LF}(K)$ locus of chickens was characterized in the present study. The results showed that similar to PRLR, $A P R L R$ is likely to encode a novel PRLR and is widely expressed in various tissues, including the skin of male chickens carrying a $K$ allele.
Moreover, $P R L$ mRNA was detected to be expressed in the skin tissue of embryos at E20 and in 1-week-old chicks. Our findings not only suggest that skin-expressed dPRLR and PRLR, together with plasma and skin-derived PRL, may play a role in the control of LF development in chicks, but also imply that dPRLR, either alone or in combination with PRLR, is actively involved in many other physiological processes, as evidenced by its wide tissue expression (Fig. 8). Therefore, the quest for fully deciphering the roles, both advantageous and disadvantageous to the poultry industry, of the $d P R L R$ gene within the sex-linked LF $K$ locus in chickens is still ongoing.

\section{Supplementary data}

This is linked to the online version of the paper at http://dx.doi.org/10.1530/ JME-13-0068.

\section{Declaration of interest}

The authors declare that there is no conflict of interest that could be perceived as prejudicing the impartiality of the research reported.

\section{Funding}

This work was supported by grants from the National Natural Science Foundation of China (30971569, 31172202, and 31271325), the National High Technology Research and Development Program of China (2013AA102501), the Open Projects of Key Laboratory of Animal Genetics, Breeding and Reproduction, College of Heilongjiang Province (GXZDSYS2012-03), the Provincial Youth Science and Technology Innovation Team Foundation of Sichuan of China (2011JTD0026), and The Chengdu City Science and Technology Bureau (12DXYB300JH).

\section{Acknowledgements}

The authors cordially thank Prof. Yang Ning (College Animal Science and Technology, China Agricultural University) for his constructive suggestions for their work.

\section{References}

Bacon LD, Smith E, Crittenden LB \& Havenstein GB 1988 Association of the slow feathering $(\mathrm{K})$ and an endogenous viral (ev21) gene on the Z chromosome of chickens. Poultry Science 67 191-197. (doi:10.3382/ps. 0670191)

Ben-Jonathan N, LaPensee CR \& LaPensee EW 2008 What can we learn from rodents about prolactin in humans? Endocrine Reviews 29 1-41. (doi:10.1210/er.2007-0017)

Bole-Feysot C, Goffin V, Edery M, Binart N \& Kelly PA 1998 Prolactin (PRL) and its receptor: actions, signal transduction pathways and phenotypes observed in PRL receptor knockout mice. Endocrine Reviews 19 225-268. (doi:10.1210/er.19.3.225)

Boulliou A, Le Pennec JP, Hubert G, Donal R \& Smiley M 1992 The endogenous retroviral ev21 locus in commercial chicken lines and its relationship with the slow-feathering phenotype (K). Poultry Science $\mathbf{7 1}$ 38-46. (doi:10.3382/ps.0710038)

Published by Bioscientifica Ltc. 
Brooks CL 2012 Molecular mechanisms of prolactin and its receptor. Endocrine Reviews 33 504-525. (doi:10.1210/er.2011-1040)

Bu G, Ying Wang C, Cai G, Leung FC, Xu M, Wang H, Huang G, Li J \& Wang Y 2013 Molecular characterization of prolactin receptor (cPRLR) gene in chickens: gene structure, tissue expression, promoter analysis, and its interaction with chicken prolactin (CPRL) and prolactin-like protein (cPRL-L). Molecular and Cellular Endocrinology 370 149-162. (doi:10.1016/j.mce.2013.03.001)

Cocolakis E, Dai M, Drevet L, Ho J, Haines E, Ali S \& Lebrun JJ 2008 Smad signaling antagonizes STAT5-mediated gene transcription and mammary epithelial cell differentiation. Journal of Biological Chemistry $\mathbf{2 8 3}$ 1293-1307. (doi:10.1074/jbc.M707492200)

Craven AJ, Ormandy CJ, Robertson FG, Wilkins RJ, Kelly PA, Nixon AJ \& Pearson AJ 2001 Prolactin signaling influences the timing mechanism of the hair follicle: analysis of hair growth cycles in prolactin receptor knockout mice. Endocrinology 142 2533-2539. (doi:10.1210/ en.142.6.2533)

Danforth CH 1929 Two factors influencing feathering in chickens. Genetics 14 256-269.

Doneen BA \& Smith TE 1982 Ontogeny of endocrine control of osmoregulation in chick embryo. II. Actions of prolactin, arginine vasopressin, and aldosterone. General and Comparative Endocrinology 48 310-318. (doi:10.1016/0016-6480(82)90142-3)

Dunnington EA, Siegel PB \& Gross WB 1986 Sex-linked feathering alleles $(\mathrm{K}, \mathrm{k}+)$ in chickens of diverse genetic backgrounds. Avian Pathology $\mathbf{1 5}$ 139-148. (doi:10.1080/03079458608436273)

Elferink MG, Vallee AA, Jungerius AP, Crooijmans RP \& Groenen MA 2008 Partial duplication of the PRLR and SPEF2 genes at the late feathering locus in chicken. BMC Genomics 9 391. (doi:10.1186/1471-2164-9-391)

Fang Q, Li J, Lu X, Nie Q, Zhang X \& Wang Y 2012 Pig signal transducer and activator of transcription $3,5 \mathrm{a}$ and $5 \mathrm{~b}$ genes: cDNA cloning, tissue expression, and identification of their transcript variants. Journal of Sichuan University (Natural Science Edition) 49 879-886.

Foitzik K, Krause K, Nixon AJ, Ford CA, Ohnemus U, Pearson AJ \& Paus R 2003 Prolactin and its receptor are expressed in murine hair follicle epithelium, show hair cycle-dependent expression, and induce catagen. American Journal of Pathology 162 1611-1621. (doi:10.1016/ S0002-9440(10)64295-2)

Foitzik K, Krause K, Conrad F, Nakamura M, Funk W \& Paus R 2006 Human scalp hair follicles are both a target and a source of prolactin, which serves as an autocrine and/or paracrine promoter of apoptosis-driven hair follicle regression. American Journal of Pathology 168 748-756. (doi:10.2353/ajpath.2006.050468)

Foitzik K, Langan EA \& Paus R 2009 Prolactin and the skin: a dermatological perspective on an ancient pleiotropic peptide hormone. Journal of Investigative Dermatology 129 1071-1087. (doi:10.1038/jid.2008.348)

Freeman ME, Kanyicska B, Lerant A \& Nagy G 2000 Prolactin: structure, function, and regulation of secretion. Physiological Reviews 80 1523-1631.

Fu X \& Porter TE 2004 Glucocorticoid induction of lactotrophs and prolactin gene expression in chicken embryonic pituitary cells: a delayed response relative to stimulated growth hormone production. Endocrinology 145 1322-1330. (doi:10.1210/en.2003-1064)

Goffin V, Shiverick KT, Kelly PA \& Martial JA 1996 Sequence-function relationships within the expanding family of prolactin, growth hormone, placental lactogen, and related proteins in mammals Endocrine Reviews 17 385-410. (doi:10.1210/edrv-17-4-385)

Goupille O, Daniel N, Bignon C, Jolivet G \& Djiane J 1997 Prolactin signal transduction to milk protein genes: carboxy-terminal part of the prolactin receptor and its tyrosine phosphorylation are not obligatory for JAK2 and STAT5 activation. Molecular and Cellular Endocrinology 127 155-169. (doi:10.1016/S0303-7207(97)04005-7)

Harris DL, Garwood VA, Lowe PC, Hester PY, Crittenden LB \& Fadly AM 1984 Influence of sex-linked feathering phenotypes of parents and progeny upon lymphoid leukosis virus infection status and egg production. Poultry Science 63 401-413. (doi:10.3382/ps.0630401)
Harvey S, Davison TF \& Chadwick A 1979 Ontogeny of growth hormone and prolactin secretion in the domestic fowl (Gallus domesticus). General and Comparative Endocrinology 39 270-273. (doi:10.1016/00166480(79)90121-7)

Iraqi F \& Smith EJ 1995 Organization of the sex-linked late-feathering haplotype in chickens. Animal Genetics 26 141-146. (doi:10.1111/j. 1365-2052.1995.tb03153.x)

Langan EA, Ramot Y, Goffin V, Griffiths CE, Foitzik K \& Paus R 2010 Mind the (gender) gap: does prolactin exert gender and/or site-specific effects on the human hair follicle? Journal of Investigative Dermatology 130 886-891. (doi:10.1038/jid.2009.340)

Lea RW, Dods AS, Sharp PJ \& Chadwick A 1981 The possible role of prolactin in the regulation of nesting behaviour and the secretion of luteinizing hormone in broody bantams. Journal of Endocrinology 91 89-97. (doi:10.1677/joe.0.0910089)

Lebrun JJ, Ali S, Goffin V, Ullrich A \& Kelly PA 1995 A single phosphotyrosine residue of the prolactin receptor is responsible for activation of gene transcription. PNAS 92 4031-4035. (doi:10.1073/ pnas.92.9.4031)

Luo C, Shen X, Rao Y, Xu H, Tang J, Sun L, Nie Q \& Zhang X 2012 Differences of $\mathrm{Z}$ chromosome and genomic expression between earlyand late-feathering chickens. Molecular Biology Reports 39 6283-6288. (doi:10.1007/s11033-012-1449-7)

Nguyen N, Stellwag EJ \& Zhu Y 2008 Prolactin-dependent modulation of organogenesis in the vertebrate: recent discoveries in zebrafish Comparative Biochemistry and Physiology. Toxicology \& Pharmacology 148 370-380. (doi:10.1016/j.cbpc.2008.05.010)

Ohkubo T, Tanaka M, Nakashima K \& Sharp PJ 1998a Relationship between prolactin receptor mRNA in the anterior pituitary gland and hypothalamus and reproductive state in male and female bantams (Gallus domesticus). General and Comparative Endocrinology 111 167-176. (doi:10.1006/gcen.1998.7099)

Ohkubo T, Tanaka M, Nakashima K, Talbot RT \& Sharp PJ 1998b Prolactin receptor gene expression in the brain and peripheral tissues in broody and nonbroody breeds of domestic hen. General and Comparative Endocrinology 109 60-68. (doi:10.1006/gcen.1997.7008)

O'Sullivan NP, Dunnington EA, Smith EJ, Gross WB \& Siegel PB 1991 Performance of early and late feathering broiler breeder females with different feeding regimens. British Poultry Science 32 981-995. (doi:10.1080/00071669108417423)

Pezet A, Ferrag F, Kelly PA \& Edery M 1997 Tyrosine docking sites of the rat prolactin receptor required for association and activation of stat5. Journal of Biological Chemistry 272 25043-25050. (doi:10.1074/jbc.272. 40.25043)

Ramot Y, Biro T, Tiede S, Toth BI, Langan EA, Sugawara K, Foitzik K, Ingber A, Goffin $\mathrm{V}$, Langbein $\mathrm{L}$ et al. 2010 Prolactin - a novel neuroendocrine regulator of human keratin expression in situ. FASEB Journal 24 1768-1779. (doi:10.1096/fj.09-146415)

Serebrovsky AS 1922 Crossing-over involving three sex-linked genes in chickens. American Naturalist 56 571-572. (doi:10.1086/279898)

Sharp PJ, Scanes CG, Williams JB, Harvey S \& Chadwick A 1979 Variations in concentrations of prolactin, luteinizing hormone, growth hormone and progesterone in the plasma of broody bantams (Gallus domesticus). Journal of Endocrinology 80 51-57. (doi:10.1677/joe.0.0800051)

Sharp PJ, Macnamee MC, Sterling RJ, Lea RW \& Pedersen HC 1988 Relationships between prolactin, LH and broody behaviour in bantam hens. Journal of Endocrinology 118 279-286. (doi:10.1677/joe.0. 1180279)

Sharp PJ, Dawson A \& Lea RW 1998 Control of luteinizing hormone and prolactin secretion in birds. Comparative Biochemistry and Physiology. Part C, Pharmacology, Toxicology \& Endocrinology 119 275-282. (doi:10.1016/S0742-8413(98)00016-4)

Smith EJ \& Fadly AM 1988 Influence of congenital transmission of endogenous virus-21 on the immune response to avian leukosis virus infection and the incidence of tumors in chickens. Poultry Science $\mathbf{6 7}$ 1674-1679. (doi:10.3382/ps.0671674) http://jme.endocrinology-journals.org DOI: 10.1530/JME-13-0068
() 2013 Society for Endocrinology Printed in Great Britain 
Somes RG Jr 1975 Pleiotrophic effects of the sex-linked delayed feathering gene, K-n, in the chicken. Poultry Science 54 208-216. (doi:10.3382/ ps.0540208)

Talbot RT, Hanks MC, Sterling RJ, Sang HM \& Sharp PJ 1991 Pituitary prolactin messenger ribonucleic acid levels in incubating and laying hens: effects of manipulating plasma levels of vasoactive intestinal polypeptide. Endocrinology 129 496-502. (doi:10.1210/endo-129-1-496)

Tanaka M, Maeda K, Okubo T \& Nakashima K 1992 Double antenna structure of chicken prolactin receptor deduced from the cDNA sequence. Biochemical and Biophysical Research Communications 188 490-496. (doi:10.1016/0006-291X(92)91082-2)

Wang Y \& Ge W 2004 Developmental profiles of activin $\beta A, \beta B$, and follistatin expression in the zebrafish ovary: evidence for their differential roles during sexual maturation and ovulatory cycle. Biology of Reproduction 71 2056-2064. (doi:10.1095/biolreprod.104. 032649)

Wang CY, Wang Y, Kwok AH \& Leung FC 2007 Identification of two novel chicken GHRH receptor splice variants: implications for the roles of aspartate 56 in the receptor activation and direct ligand receptor interaction. Journal of Endocrinology 195 525-536. (doi:10.1677/JOE-07-0167)
Wang X, Nahashon S, Feaster TK, Bohannon-Stewart A \& Adefope N 2010a An initial map of chromosomal segmental copy number variations in the chicken. BMC Genomics 11 351. (doi:10.1186/1471-2164-11-351)

Wang Y, Li J, Yan Kwok AH, Ge W \& Leung FC 2010b A novel prolactin-like protein (PRL-L) gene in chickens and zebrafish: cloning and characterization of its tissue expression. General and Comparative Endocrinology 166 200-210. (doi:10.1016/j.ygcen.2009.10.007)

Wang Y, Meng F, Zhong Y, Huang G \& Li J 2012a Discovery of a novel glucagonlike peptide (GCGL) and its receptor (GCGLR) in chickens: evidence for the existence of GCGL and GCGLR genes in nonmammalian vertebrates. Endocrinology 153 5247-5260. (doi:10.1210/en.2012-1586)

Wang Y, Wang CY, Wu Y, Huang G, Li J \& Leung FC 2012b Identification of the receptors for prolactin-releasing peptide (PrRP) and Carassius RFamide peptide (C-RFa) in chickens. Endocrinology 153 1861-1874. (doi:10.1210/en.2011-1719)

Woods KL \& Porter TE 1998 Ontogeny of prolactin-secreting cells during chick embryonic development: effect of vasoactive intestinal peptide. General and Comparative Endocrinology 112 240-246. (doi:10.1006/gcen.1998.7168)

Zhu Y, Stiller JW, Shaner MP, Baldini A, Scemama JL \& Capehart AA 2004 Cloning of somatolactin alpha and beta cDNAs in zebrafish and phylogenetic analysis of two distinct somatolactin subtypes in fish. Journal of Endocrinology 182 509-518. (doi:10.1677/joe.0.1820509)

Received in final form 3 August 2013

Accepted 12 August 2013

Accepted Preprint published online 12 August 2013
(C) 2013 Society for Endocrinology Printed in Great Britain
Published by Bioscientifica Ltd. 